DOI: 10.14720/aas.2016.107.2.02

Agrovoc descriptors: punica granatum, pomegranates, varieties, chemicophysical properties, antioxidants, ascorbic acid, phenolic compounds, aromatic compounds

Agris category code: F01, Q04

\title{
Physicochemical properties and antioxidant activities of five Iranian pomegranate cultivars (Punica granatum $L$.) in maturation stage
}

\author{
Kosar NIKDEL ${ }^{1}$, Esmaiel SEIFI ${ }^{2}$, Hamed BABAIE $^{1 *}$, Mehdi SHARIFANI $^{2}$, Khodayar HEMMATI ${ }^{2}$
}

Received April 14, 2015; accepted May 03, 2016.

Delo je prispelo 14. aprila 2015, sprejeto 03. maja 2016.

\begin{abstract}
The aim of this study was to compare the physicochemical properties and antioxidant activity of five different pomegranate cultivars. Fruit mass ranged from 109.27 to $78.07 \mathrm{~g}$. Peel thickness of the fruit was recorded from 5.05 to $2.70 \mathrm{~mm}$. The $\mathrm{pH}$, total soluble solids content, the titratable acidity content were within the range of 4.23 to $4.36,20.00$ ( ${ }^{\circ}$ Brix) to 14.05 ( ${ }^{\circ}$ Brix), 0.04 to $0.007 \mathrm{mg}$ per $100 \mathrm{~g}$ of juice, respectively. Ascorbic acid content was from 4.73 to $1.98 \mathrm{mg}$ per $100 \mathrm{~g}$ of juice. The amount of total phenolics in pomegranate cultivars was between 6.36 and $1.78 \mathrm{mg}$ $\mathrm{GAE} / 100 \mathrm{ml}$. The total flavonoids content also ranged between 4.93 to $2.24 \mathrm{mg}$ GAE/100 $\mathrm{ml}$. The level of antioxidant activity was varied from $86.77 \%$ to $79.54 \%$. Reducing sugar content ranged between 5.81 to $1.72 \mathrm{mg} / 100 \mathrm{~g}$. Glucose content was found from 3.48 to $1.14 \mathrm{mg} / 100 \mathrm{~g}$. In total based on these results, the cultivar is the main parameter which influences the physic-chemical properties and antioxidant activity in pomegranates.
\end{abstract}

Key words: ascorbic acid; maturity index; phenolic compounds; physicochemical properties; pomegranate

\section{IZVLEČEK}

FIZIKALNO-KEMIJSKE LASTNOSTI IN ANTIOKSIDACIJSKA AKTIVNOST PETIH IRANSKIH SORT GRANATNEGA JABOLKA (Punica granatum L.) V ČASU ZRELOSTI

\begin{abstract}
Namen raziskave je bil primerjati fizikalno-kemijske lastnosti in antioksidacijsko aktivnost petih sort granatnega jabolka Masa plodov je bila med 109.27 in 78.07 g. Debelina olupka je znašala od 5.05 do $2.70 \mathrm{~mm}$. $\mathrm{pH}$, celokupna vsebnost topnih snovi in vsebnost titrabilne kislosti so bili v območju 4.23 do 4.36, 20.00 (०Brix) do 14.05 (०Brix), 0.04 do $0.007 \mathrm{mg}$ na $100 \mathrm{~g}$ soka. Vsebnost askorbinske kisline je bila med 4.73 in $1.98 \mathrm{mg}$ na $100 \mathrm{~g}$ soka. Vsebnost celokupnih fenolov je bila med 6.36 in $1.78 \mathrm{mg}$ GAE/100 ml, vsebnost celokupnih flavonoidov pa med 4.93 in $2.24 \mathrm{mg}$ GAE $/ 100 \mathrm{ml}$. Antioksidacijska aktivnost je variirala med $86.77 \%$ in $79.54 \%$. Vsebnost reducirajočih sladkorjev je bila med 5.81 in $1.72 \mathrm{mg} / 100 \mathrm{~g}$, vsebnost glukoze pa med 3.48 in $1.14 \mathrm{mg} / 100 \mathrm{~g}$. Iz rezultatov sledi, da je sorta najpomembnejši dejavnik, ki vpliva na fizikalno-kemijske lastnosti in antioksidacijsko aktivnost granatnega jabolka.
\end{abstract}

Ključne besede: askorbinska kislina; indeks zrelosti; fenolne spojine fizikalno.kemijske lastnosti; granatno jabolko

\section{INTRODUCTION}

Pomegranate (Punica granatum L.) is an important commercial fruit that is cultivated in many tropical and subtropical climates including Asia, North Africa, the Mediterranean and the Middle East (Khoshnam et al., 2007; Sarkhosh et al., 2006). Iran is one of the most important pomegranate producer and exporter in the world (Anonymous, 2005; Tehranifar \& Mahmoodi-Tabar, 2009). Pomegranate cultivation has a long tradition in Iran. It is considered one of the most important fresh fruits in this country (Barone et al., 2001). It is now widely grown in many tropical and

\footnotetext{
M.Sc. student of department of Horticultural Science, Gorgan University of Agricultural Sciences and Natural Resources, Gorgan, Iran; corresponding author: hamed.aha66@yahoo.com

2 Ph.D. of department of Horticultural Science, Gorgan University of Agricultural Sciences and Natural Resources, Gorgan, Iran
} 
subtropical regions in Iran. The total production of pomegranate in Iran was 670,000 tons in 2005 (Anonymous, 2005).

Different parts of pomegranate trees and the fruit have been used directly for their medicinal properties and for other purposes such as juice, jams, syrup and sauce (Al-Maiman \& Ahamad, 2002; Rania et al., 2008). Considerable amounts of acids, sugars, vitamins, polysaccharides, polyphenols, important minerals and high antioxidant activity extracts have been obtained ?? from different part of pomegranate fruit such as peel, juice and seeds (Ercisli et al., 2007; Gil et al., 2000; Ozgen et al., 2008; Singh et al., 2002).

Olaniyi et al., (2010) evaluated the physicochemical and antioxidant properties of three cultivars of pomegranate grown in the South Africa. The results showed that there is a significant difference in physicochemical properties and antioxidant activity among cultivars. The compounds of pomegranate fruit are highly dependent on the cultivar type, growing region, climate, maturity and cultural practice (Melgarejo et al., 2000; Olaniyi et al., 2010; Ozgan et al., 2008; Ozken et al., 2002).
Various reports have shown that cultivar influences the antioxidant activity and other physicochemical properties, such as peel and juice percentage, dry matter, $\mathrm{pH}$, total soluble solids (TSS), total sugars, titratable acidity (TA), total phenolics, anthocyanins, organic acids and water-soluble vitamins composition (Al-Maiman \& Ahmad, 2002; Al-Said et al., 2009; Kulkarni \& Aradhya, 2005; Mousavinejad et al., 2009; Melgarejo \& Artes, 2000; Tezcan et al., 2009).

Martinez et al., (2006) studied five varieties of pomegranate from Southeast Spain. They measured the morphological and chemical characteristics such as $\mathrm{pH}$, TSS, maturity and harvest index. They showed that there was significant difference among the cultivars and that cultivar plays an important role in determining physicochemical properties.

This research is focused on the variation among pomegranate fruits of six cultivars from the perspective of morphological and physiochemical properties. The aim of the present study was to determine and compare the variability in the juice and peel physicochemical characteristics and antioxidant activity and other physical and chemical properties.

\section{MATERIALS AND METHODS}

\subsection{Plant material}

Pomegranate fruit harvest criteria was based on local and commercial harvest time. The fruits were harvested at commercially ripe stage in september 2012 from five main cultivars such as 'Rubbab', 'Ghand', 'Shishe-Kap', 'Shahvar', 'Shalghami ' from different mature trees (10 to 12-year-old) randomly selected in Ferdows, Khorasan Jonoubi, Iran (between 39-32 degrees up to 42-43 degrees north latitude and 5-75 up to 55-58 degrees east longitude is located). The city due to its geographical location and the proximity to the desert has tropical climate. The average rainfall in this city is about $155 \mathrm{~mm}$ per year. General characteristics of the cultivars are as follows: 'Rubbab': sour-sweet, red and thickened skin; seed color is red, average fruit mass: $95.012 \mathrm{~g}$. 'Ghand': sweet, white and thickened skin, seed color is white, average fruit mass: 70.08 g. 'Shishe-Kap': sour-sweet, red and relatively thin skin, seed color is pink, average fruit mass: $109.027 \mathrm{~g}$. 'Shahvar': sweet, red and thin skin, seed color is candy, average fruit mass: $80.94 \mathrm{~g}$. 'Shalghami': sour, red and relatively thin skin, seed color is red, average fruit mass: $78.42 \mathrm{~g}$. After harvest, fruits were quickly transported in cold bag to the research laboratory at Gorgan university of agricultural sciences and natural resources. The ripe fresh fruits were from different mature trees randomly (completely randomized design of four trees per variety in a sample of twelve fruits per replications) selected to represent the population of the plantation.

\subsection{Morphological Properties}

Harvested fruits were sorted for size and uniformity of shape and mass. All fruits were first flushed by tap water before the peel, pulp and seed 
fractions were carefully separated. The peel and pulp were separated manually after measurement of fruit fresh mass, volume and fruit density. Fruits were weighted in the air on a balance of accuracy of $0.001 \mathrm{~g}$. Fruit volume was calculated by a liquid displacement method. The mass density of the fruit was obtained by the ratio of mass to volume. The length and diameter of the fruit and arils, length and diameter of calyx were measured with a digital vernier calliper. The measurement of fruit length was made on the polar axis, i.e. between the apex and the end of stem. The maximum width of the fruit, as measured in the direction perpendicular to the polar axis, is defined as the diameter. Then peel thickness was measured by a digital calliper with $0.01 \mathrm{~mm}$ accuracy and oven-dried $\left(105^{\circ} \mathrm{C}\right)$ to constant mass to calculate its moisture content. Aril, juice and seed mass were measured as above. Then the arils and juices were analyzed for major chemical compositions and antioxidant activity.

\subsection{Chemical Analysis}

The total soluble solids (TSS) in the juice $\left({ }^{\circ}\right.$ Brix) were determined with a digital refractrometer (060279, Ceit, Belgium), at $20^{\circ} \mathrm{C}$, calibrated using distilled water. Titrable acidity was estimated by juice titration with $0.1 \mathrm{~N} \mathrm{NaOH}$ to the titration end point of $\mathrm{pH} 8.3$, monitored with a $\mathrm{pH}$ meter (Labtron) and expressed as citric acid per $100 \mathrm{~g}$ of juice. The $\mathrm{pH}$ measurements were performed using a digital $\mathrm{pH}$ meter (Labtron, Iran) at $21{ }^{\circ} \mathrm{C}$, calibrated using distilled water). For electrical conductivity (EC, dSm 1) determination, the sample was measured with a conductivimeter (ABB-100).

Ascorbic acid was determined by employing the method described by Kashyap \& Gautam (2012). Results were expressed as mg per $100 \mathrm{~g}$ of juice.
Reducing sugars were measured according to the method of Maccready et al. (2000). Glucose and fructose were determined by Miller (1959) and Ashwell (1957), respectively and expressed as mg sugar $100 \mathrm{~g}$ of juice.

Total phenolics were measured calorimetrically at $760 \mathrm{~nm}$ by using the Folin-Ciocalteu reagent (Singleton \& Rossi, 1965). Gallic acid was used as a standard. The results were expressed as $\mathrm{mg}$ Gallic acid equivalent in $100 \mathrm{~g}$ of fruit juice (mg $\mathrm{GAE} / 100 \mathrm{~g}$ of juice).

The total flavonoids content was measured by using Yang method (Yang et al., 2009). $250 \mu 1$ of pomegranate juice sample was mixed with $5 \%$ sodium nitrite solution $(75 \mu \mathrm{l})$, then the mixture was mixed with aluminium chloride (10 \%, $150 \mu \mathrm{l})$, sodium hydroxide $(1 \mathrm{M}, 500 \mu \mathrm{l})$ and distilled water $(775 \mu \mathrm{l})$. The absorbance of the mixture was measured spectrophotometrically at $510 \mathrm{~nm}$. Total flavonoid content was expressed as mg per $100 \mathrm{~g}$ of juice.

Antioxidant activity was assessed according to the method of Sun \& Ho. (2005). $30 \mu 1$ of pomegranate juice was mixed with $2 \mathrm{ml}$ of $0.1 \mathrm{mM} \mathrm{DPPH}$ in methanol and the mixtures was $1 \mathrm{ml}$. After 15 minutes, absorbance of the resulting solution was measured at $515 \mathrm{~nm}$ by a spectrophotometer. The antioxidant activity was calculated using the following equation: antioxidant activity $(\%)=[1-($ sample $515 \mathrm{~nm} /$ control $515 \mathrm{~nm})] \times 100$.

\subsection{Statistical Analysis}

Data were analyzed by Statistical Analysis System (SAS) software and mean comparison was done using Least Significant Difference (LSD) test in level $5 \%$.

\section{RESULTS AND DISCUSSION}

\subsection{Physical properties}

A considerable variation was observed in some of the physical-chemical and antioxidant properties of studied pomegranate cultivars. The physical characteristics of five pomegranate cultivars analyzed are described in Tables 1. Significant difference were detected in length, length/diameter, juice volume, calyx length, peel thickness, length of aril, seed diameter and moisture $(P<0.01)$, mass and peel moisture $(P<0.05)$, while there were not showed significant differences in traits of diameter, width, volume, density and calyx diameter of fruits. 
The maximum fruit mass of pomegranate cultivars was in 'Shishe-Kap' (109.27 g) and the minimum fruit mass were found in 'Ghand', 'Shalghami', 'Shahvar' (78.07, 78.42, 80.94 g, respectably) (Table 2). Main comparison of the results (Table 2) indicated that the highest of length/diameter ratio was in 'Shishe-Kap' $(1.29 \mathrm{~mm})$ and the lowest of length /diameter ratio were in 'Shahvar' $(0.91 \mathrm{~mm})$, 'Ghand' $(0.89 \mathrm{~mm})$ and 'Shalghami' $(0.86 \mathrm{~mm})$. The highest fruit length $(109.27 \mathrm{~mm})$ and the lowest fruit length $(78.42 \mathrm{~mm})$ were recorded in 'Shishe-Kap' and 'Shalghami', respectably (Table 2).

'Shalghami' and 'Ghand' fruits had the maximum $(17.99 \mathrm{~mm})$ and minimum $(9.62 \mathrm{~mm})$ calyx length, respectively and showed a significant difference to other studied cultivars (Table 2).

'Ghand' had the highest aril length $(11.98 \mathrm{~mm})$ and aril diameter $(8.38 \mathrm{~mm})$ while 'Rubab' and 'Shalghami' had the lowest aril length $(10.61 \mathrm{~mm}$ and $10.70 \mathrm{~mm}$ respectively), The minimum of aril diameter was observed in 'Shahvar' $(6.93 \mathrm{~mm})$ (Table 2). The fruit peel thickness varied from 5.05 ('Ghand' and 'Rubab') to $2.70 \mathrm{~mm}$ ('Shahvar') (Table 2). The highest peel moisture was in 'Shalghami' (58.88 \%), 'Shishe-Kap' (57.51\%) and 'Shahvar' (56.89\%). There were no significant differences among these three cultivars in terms of peel moisture. The lowest peel moisture was found in 'Ghand' (51.15\%) (Table 2). 'Ghand' and 'Rubab' fruits had the maximum $(68.37 \%)$ and minimum $(56.55 \%)$ seed moisture, respectively. In several studies, a wide variation was showed that the fruit mass, fruit length, fruit diameter, calyx length and calyx diameter of pomegranate fruits grown in Iran are between $169.89 \mathrm{~g}-315.28 \mathrm{~g} ; 69.49 \mathrm{~mm}-81.46 \mathrm{~mm} ; 64.98$ $\mathrm{mm}-86.88 \mathrm{~mm} ; 13.45 \mathrm{~mm}-24 \mathrm{~mm} ; 12.52 \mathrm{~mm}$ $23.96 \mathrm{~mm}$ respectively (Thehranifar et al., 2010; Sarkhosh et al., 2006). Our results in general were close to these studies and showed these differences among cultivars. These differences may be related to the design or selection of appropriate packaging for fruit handling and storage (Valero \& RuizAltisent, 2000). According to reports, the existence of significant differences in morphology is relevant to development of the fruit (Zarei et al., 2011). Shulman et al. (1984) reported that these differences of fruit could be attributed to the cultivars type and ecological condition. The juice percentage ranged between $30.21 \%$ ('Shahvar') and $16.46 \%$ ('Rubab') (Table 2). Tehranifar et al. (2010) stated the juice percentage varied from $26.95 \%$ to $46.55 \%$. The juice percentage is one of the most important parameters from an industrial point (Tehranifar et al. 2010). 
Table 1: Analysis of variance of fruit mass (FM), fruit length (FL), fruit diameter (FD), fruit length/diameter (F 1/d), fruit width (FW $)$, fruit volume (FV), fruit densities (FDs), juice volume (JV), calyx length (CL), calyx diameter (CD), peel moisture (PM), peel thickness (PT), aril length (AL), aril diameter (AD), seed moisture (SM) of the studied Iranian pomegranate cultivars

\begin{tabular}{|c|c|c|c|c|c|c|c|c|c|c|c|c|c|c|c|c|}
\hline \multirow[b]{2}{*}{$\begin{array}{l}\text { Source of } \\
\text { variation }\end{array}$} & \multirow[b]{2}{*}{$\mathrm{df}$} & \multicolumn{15}{|c|}{ MS } \\
\hline & & $\begin{array}{l}\text { FM } \\
(\mathrm{g})\end{array}$ & $\begin{array}{c}\text { FL } \\
(\mathrm{mm})\end{array}$ & $\begin{array}{c}\text { FD } \\
(\mathrm{mm})\end{array}$ & F $1 / d$ & $\begin{array}{l}\mathrm{FW}_{\mathrm{i}} \\
(\mathrm{mm})\end{array}$ & $\begin{array}{c}\mathrm{FV} \\
\left(\mathrm{cm}^{3}\right)\end{array}$ & $\begin{array}{c}\mathrm{FD}_{\mathrm{S}} \\
(\mathrm{g} / \mathrm{cm} 3)\end{array}$ & $\begin{array}{c}\text { JV } \\
(\%)\end{array}$ & $\begin{array}{c}\text { CL } \\
(\mathrm{mm})\end{array}$ & $\begin{array}{c}\mathrm{CD} \\
(\mathrm{mm})\end{array}$ & $\begin{array}{l}\text { PM } \\
(\%)\end{array}$ & $\begin{array}{c}\text { PT } \\
(\mathrm{mm})\end{array}$ & $\begin{array}{c}\mathrm{AL} \\
(\mathrm{mm})\end{array}$ & $\begin{array}{c}\mathrm{AD} \\
(\mathrm{mm})\end{array}$ & $\begin{array}{l}\text { SM } \\
(\%)\end{array}$ \\
\hline Cultivars & 4 & $52.32^{*}$ & $12.23^{* *}$ & $60.73^{\mathrm{ns}}$ & $0.20^{* *}$ & $36.300^{\mathrm{ns}}$ & $4500.68^{\mathrm{ns}}$ & $0.062^{\mathrm{ns}}$ & $231.44^{* *}$ & $53.89^{* *}$ & $178.28^{\mathrm{ns}}$ & $60.20^{* *}$ & $5.22^{* *}$ & $2.094^{* *}$ & $3.086^{* *}$ & $41.03^{* *}$ \\
\hline Error & 28 & 6293.19 & 68.17 & 55.71 & 0.0029 & 64.31 & 5109.63 & 0.048 & 16.14 & 12.37 & 157.084 & 16.54 & 0.557 & 0.29 & 0.237 & 9.90 \\
\hline $\mathrm{CV} \%$ & & 22.5 & 9.31 & 8.35 & 5.40 & 9.33 & 20.12 & 21.92 & 18.66 & 28.53 & 63.73 & 7.31 & 19.90 & 4.89 & 6.18 & 5.19 \\
\hline
\end{tabular}

Note: (ns) No significant differences, $(* * \& *)$ : significant difference at $1 \%$ and $5 \%$ level, respectively

Table 2: fruit mass (FM), fruit length (FL), fruit diameter (FD), fruit length/diameter (F 1/d), fruit width (FWi), fruit volume (FV), fruit densities (FDs), juice volume (JV), calyx length (CL), calyx diameter (CD), peel moisture (PM), peel thickness (PT), aril length (AL), aril diameter (AD), seed moisture (SM) of five Iranian pomegranate cultivars

\begin{tabular}{|c|c|c|c|c|c|c|c|c|c|c|c|c|c|c|c|}
\hline Cultivars & $\begin{array}{l}\text { FM } \\
(\mathrm{g})\end{array}$ & $\begin{array}{c}\text { FL } \\
(\mathrm{mm})\end{array}$ & $\begin{array}{c}\text { FD } \\
(\mathrm{mm})\end{array}$ & F $1 / d$ & $\begin{array}{l}\mathrm{FW}_{\mathrm{i}} \\
(\mathrm{mm})\end{array}$ & $\begin{array}{c}\mathrm{FV} \\
\left(\mathrm{cm}^{3}\right)\end{array}$ & $\begin{array}{c}\mathrm{FD}_{\mathrm{S}} \\
\left(\mathrm{g} / \mathrm{cm}^{3}\right)\end{array}$ & $\begin{array}{l}\text { JV } \\
(\%)\end{array}$ & $\begin{array}{c}\mathrm{CL} \\
(\mathrm{mm})\end{array}$ & $\begin{array}{c}\mathrm{CD} \\
(\mathrm{mm})\end{array}$ & $\begin{array}{l}\mathrm{PM} \\
(\%)\end{array}$ & $\begin{array}{c}\text { PT } \\
(\mathrm{mm})\end{array}$ & $\begin{array}{c}\mathrm{AL} \\
(\mathrm{mm})\end{array}$ & $\begin{array}{c}\mathrm{AD} \\
(\mathrm{mm})\end{array}$ & $\begin{array}{l}\text { SM } \\
(\%)\end{array}$ \\
\hline & $P<0 / 0001$ & $\begin{array}{c}P< \\
0 / 0001 \\
\end{array}$ & $\begin{array}{c}<< \\
0 / 0001 \\
\end{array}$ & $\begin{array}{c}P< \\
0 / 0001 \\
\end{array}$ & $\begin{array}{c}P< \\
0 / 0001 \\
\end{array}$ & $\begin{array}{c}P< \\
0 / 0001 \\
\end{array}$ & $\begin{array}{c}P< \\
0 / 0001 \\
\end{array}$ & $\begin{array}{c}P< \\
0 / 0001 \\
\end{array}$ & $\begin{array}{c}P< \\
0 / 0001 \\
\end{array}$ & $\begin{array}{c}P< \\
0 / 0001 \\
\end{array}$ & $\begin{array}{c}P< \\
0 / 0001 \\
\end{array}$ & $\begin{array}{c}P< \\
0 / 0001 \\
\end{array}$ & $\begin{array}{c}P< \\
0 / 0001 \\
\end{array}$ & $\begin{array}{c}P< \\
0 / 0001 \\
\end{array}$ & $\begin{array}{c}P< \\
0 / 0001 \\
\end{array}$ \\
\hline 'Ghand' & $78.07^{\mathrm{c}}$ & $97.68^{b}$ & $90.46^{\mathrm{a}}$ & $0.89^{c}$ & $85.35^{\mathrm{a}}$ & $333.25^{\mathrm{a}}$ & $0.233^{\mathrm{a}}$ & $20.58 b^{c}$ & $9.62^{\mathrm{c}}$ & $9.62^{\mathrm{a}}$ & $51.15^{\mathrm{b}}$ & $5.05^{\mathrm{a}}$ & $11.98^{\mathrm{a}}$ & $8.38^{\mathrm{a}}$ & $68.37^{\mathrm{a}}$ \\
\hline 'Shahvar' & $80.94^{\mathrm{c}}$ & $98.94^{\mathrm{b}}$ & $89.50^{\mathrm{a}}$ & $0.91^{\mathrm{c}}$ & $84.55^{\mathrm{a}}$ & $336.13^{\mathrm{a}}$ & $0.240^{\mathrm{a}}$ & $30.21^{\mathrm{a}}$ & $12.83^{\mathrm{b}}$ & $10.83^{\mathrm{a}}$ & $56.89^{\mathrm{a}}$ & $2.70^{\mathrm{c}}$ & $11.09^{b}$ & $6.93^{\mathrm{b}}$ & $61.58^{\mathrm{b}}$ \\
\hline $\begin{array}{l}\text { 'Shishe- } \\
\text { Kap' }\end{array}$ & $\begin{array}{c}109.027 \\
\mathrm{a}\end{array}$ & $109.27^{\mathrm{a}}$ & $88.19^{\mathrm{a}}$ & $1.29^{\mathrm{a}}$ & $83.65^{\mathrm{a}}$ & $330.00^{\mathrm{a}}$ & $0.302^{\mathrm{a}}$ & $16.79^{c}$ & $12.76^{\mathrm{b}}$ & $10.76^{\mathrm{a}}$ & $57.51^{\mathrm{a}}$ & $3.60^{\mathrm{b}}$ & $11.06^{\mathrm{b}}$ & $8.35^{\mathrm{a}}$ & $61.12^{\mathrm{b}}$ \\
\hline 'Rubab’ & $95.012^{b}$ & $98.006^{\mathrm{b}}$ & $91.14^{\mathrm{a}}$ & $1.065^{\mathrm{b}}$ & $85.63^{\mathrm{a}}$ & $331.28^{\mathrm{a}}$ & $0.262^{\mathrm{a}}$ & $16.46^{\mathrm{c}}$ & $13.50^{\mathrm{b}}$ & $9.50^{\mathrm{a}}$ & $55.66^{\mathrm{ab}}$ & $5.05^{\mathrm{a}}$ & $10.61^{\mathrm{c}}$ & $8.24^{\mathrm{a}}$ & $56.55^{\mathrm{c}}$ \\
\hline 'Shalghami & $78.42^{\mathrm{c}}$ & $78.42^{\mathrm{c}}$ & $90.69^{\mathrm{a}}$ & $0.86^{\mathrm{c}}$ & $84.29^{\mathrm{a}}$ & $335.00^{\mathrm{a}}$ & $0.234^{\mathrm{a}}$ & $21.95^{\mathrm{b}}$ & $17.99^{\mathrm{a}}$ & $10.99^{\mathrm{a}}$ & $58.88^{\mathrm{a}}$ & $3.89^{\mathrm{b}}$ & $10.70^{\mathrm{c}}$ & $7.39^{\mathrm{b}}$ & $59.80^{\mathrm{cb}}$ \\
\hline
\end{tabular}

Note: The dissimilar letters in each column indicate significant differences between them 


\subsection{Chemical properties}

The chemical characteristics of five pomegranate cultivars analyzed are described in Tables 3 . Chemical properties of studied pomegranate fruits showed significant differences in all parameters $(P<0.01)$ except the fructose. The highest of $\mathrm{pH}$ were in 'Ghand' (4.36) and 'Shishe-Kap' (4.23). The lowest of $\mathrm{pH}$ were in 'Rubab' (3.78) and 'Shalghami' (3.78) (Table 4). This parameter defines the acidic taste of pomegranate juice (Zarei et al., 2011). The $\mathrm{pH}$ values observed in the present study are higher than values that reported by Cam et al. (2009) on pomegranate cultivars (from 2.82 to 0.81 ). The results of our study are indicative of the lower levels of $\mathrm{H}^{+}$.

The maximum of electrical conductivity (Ec) was found in 'Shalghami' $(48.2 \mathrm{~S} / \mathrm{m})$ and the minimum was in 'Ghand' (32.3 S/m) (Table 4). Akbarpour et al. (2009) reported that EC value of some pomegranate cultivars in Iran was between 3.41 and $5.1123 \mathrm{mmohs} / \mathrm{cm}$. The total soluble solid values ranged between $20.00{ }^{\circ}$ Brix ('Rubab') to $14.05^{\circ}$ Brix ('Shahvar') (Table 4). Our results were in agreement with values (15.17-22.03 ${ }^{\circ}$ Brix) reported by Akbarpour et al. (2009), while our values were higher than values observed (11.37$15.07{ }^{\circ}$ Brix) by Tehranifar et al. (2010). The titrable acidity content varied from $0.040 \mathrm{mg}$ per $100 \mathrm{~g}$ of juice ('Shahvar') to $0.007 \mathrm{mg}$ per $100 \mathrm{~g}$ of juice ('Ghand') (Table 4). Citric acid is the predominant acid in pomegranate (Varidi, 1992). Kulkarni \& Aradhia (2005) stated that acidity decreases at the time of maturation and is associated with increasing in the sugar content. The highest content of ascorbic acid was in 'Shalghami' (4.73) and the lowest in 'Rubab' (1.98 mg per $100 \mathrm{~g}$ of juice), 'Ghand' (2.26 mg per 100 $\mathrm{g}$ of juice) and 'Shishe-Kap' (2.09 mg per $100 \mathrm{~g}$ of juice) (Table 4). According to our results, the cultivars have a very important role in the amount of total soluble solids, $\mathrm{pH}$ and titratable acidity and vitamin C (Tehranifar et al., 2010).

According to Table 2, there are significant differences among the studied cultivars. Some researchers used maturity index for classifying of pomegranate cultivars (Cam et al., 2009; Martinez et al., 2006; Melgarejo et al., 2000, Tehranifar et al., 2010). Martinez et al. (2006) stated that the maturity index in some Spain varieties of pomegranate were in the range of $25 / 16$ to $94 / 56$. Other researchers have noted wide ranges for this parameter. For example, Sharman \& Bist (2005) reported that MI value was 95.16. Following classification was proposed by Martinez et al. (2006) for the values of maturity index in Spanish cultivars: maturity index (MI) $=5-7$ for sour, $\mathrm{MI}=17$ - 24 for sour - sweet and MI = $31-98$ for sweet cultivars. Based on these results, all our studied cultivars can be classified as sweet, because their maturity index range were between 98 to 31 . The ratio of sugar to acid is a determining factor in fruit flavors. Quality of the cultivars depends in this factor. Cam et al. (2009) and Martinez et al. (2006) stated the maturity index (TSS/TA) is responsible for the taste and flavor of pomegranate. 
Table 3: Analysis of variance of $\mathrm{pH}$, electrical conductivity (EC), total soluble solid (TSS), titrable acidity (TA), maturity index (MI), ascorbic acid (A), total phenolic(TPh), total flavonoids (TFl), antioxidant activity (AA), reducing sugar(RS), glucose(Gl), fructose (Fr) of the studied Iranian pomegranate cultivars.

\begin{tabular}{|c|c|c|c|c|c|c|c|c|c|c|c|c|c|}
\hline \multirow[b]{2}{*}{$\begin{array}{l}\text { Source of } \\
\text { variation }\end{array}$} & \multirow[b]{2}{*}{$\mathrm{df}$} & \multicolumn{12}{|c|}{ MS } \\
\hline & & $\mathrm{pH}$ & $\begin{array}{c}\mathrm{EC} \\
(\mathrm{S} / \mathrm{m})\end{array}$ & $\begin{array}{l}\text { TSS } \\
\left({ }^{\circ} \mathrm{B}\right)\end{array}$ & $\begin{array}{c}\text { TA } \\
(\mathrm{mg} / 100 \\
\text { gr) }\end{array}$ & MI & $\begin{array}{c}\mathrm{A} \\
(\mathrm{mg} / 100 \mathrm{ml})\end{array}$ & $\begin{array}{c}\mathrm{TPh} \\
(\mathrm{mg} \mathrm{GAE} / \\
100 \mathrm{ml})\end{array}$ & $\begin{array}{c}\text { TFl } \\
(\mathrm{mg} \mathrm{GAE} / \\
100 \mathrm{ml})\end{array}$ & $\begin{array}{l}\text { AA } \\
(\%)\end{array}$ & $\begin{array}{c}\text { RS } \\
(\mathrm{mg} / 100 \mathrm{~g})\end{array}$ & $\begin{array}{c}\text { Gl } \\
(\mathrm{mg} / 100 \mathrm{~g})\end{array}$ & $\begin{array}{c}\text { Fr } \\
(\mathrm{mg} / 100 \mathrm{~g})\end{array}$ \\
\hline Cultivars & 4 & $0.43^{* *}$ & $2.43^{* *}$ & $33.72^{* *}$ & $0.0010^{* *}$ & $20.07^{* *}$ & $6.64^{* *}$ & $23.76^{* *}$ & $10.47^{* *}$ & $58.062^{* *}$ & $22.089^{* *}$ & $8.63^{* *}$ & $0.8^{* *}$ \\
\hline Error & 28 & 0.017 & 0.101 & 3.72 & 0.009 & 1.29 & 1.66 & 3.71 & 34.29 & 0.93 & 0.93 & 0.423 & 0.582 \\
\hline CV \% & & 3.207 & 7.97 & 11.60 & 56.21 & 13.62 & 15.66 & 35.47 & 50.08 & 7.035 & 28.74 & 27.12 & 88.25 \\
\hline
\end{tabular}

Table 4: $\mathrm{pH}$, electrical conductivity (EC), total soluble solid (TSS), titrable acidity (TA), maturity index (MI), scorbic acid (A), total phenolic(TPh), total flavonoids (TFl), antioxidant activity (AA), reducing sugar(RS) glucose(Gl) fructose (Fr) of five Iranian pomegranate cultivars

\begin{tabular}{|c|c|c|c|c|c|c|c|c|c|c|c|c|}
\hline Cultivars & $\mathrm{pH}$ & $\begin{array}{c}\mathrm{EC} \\
(\mathrm{S} / \mathrm{m})\end{array}$ & $\begin{array}{l}\text { TSS } \\
\left({ }^{\circ} \mathrm{B}\right)\end{array}$ & $\begin{array}{c}\text { TA } \\
(\mathrm{mg} / 100 \mathrm{gr})\end{array}$ & MI & $\begin{array}{c}\text { A } \\
(\mathrm{mg} / 100 \mathrm{ml})\end{array}$ & $\begin{array}{c}\mathrm{TPh} \\
(\mathrm{mg} \mathrm{GAE} / \\
100 \mathrm{ml})\end{array}$ & $\begin{array}{c}\text { TFl } \\
(\mathrm{mg} \mathrm{GAE} / \\
100 \mathrm{ml})\end{array}$ & $\begin{array}{l}\mathrm{AA} \\
(\%)\end{array}$ & $\begin{array}{c}\mathrm{RS} \\
(\mathrm{mg} / 100 \\
\mathrm{g})\end{array}$ & $\begin{array}{c}\mathrm{Gl} \\
(\mathrm{mg} / 100 \\
\mathrm{g})\end{array}$ & $\begin{array}{c}\text { Fr } \\
(\mathrm{mg} / 100 \mathrm{~g})\end{array}$ \\
\hline & $P<0 / 0001$ & $P<0 / 0001$ & $P<0 / 0001$ & $P<0 / 0001$ & $P<0 / 0001$ & $P<0 / 0001$ & $P<0 / 0001$ & $P<0 / 0001$ & $P<0 / 0001$ & $P<0 / 0001$ & $P<0 / 0001$ & $P<0 / 0001$ \\
\hline 'Ghand' & $4.36^{\mathrm{a}}$ & $32.3^{c}$ & $16.27 b^{c}$ & $0.0078^{c}$ & $100.59^{\mathrm{a}}$ & $2.26^{\mathrm{c}}$ & $1.78^{\mathrm{c}}$ & $3.30^{\mathrm{ab}}$ & $83.43^{b c}$ & $5.81^{\mathrm{a}}$ & $3.48^{\mathrm{a}}$ & $1.11^{\mathrm{a}}$ \\
\hline 'Shahvar' & $4.03^{b}$ & $44.3^{b}$ & $14.05^{\mathrm{b}}$ & $0.040^{\mathrm{a}}$ & $73.11^{\mathrm{d}}$ & $3.30^{\mathrm{b}}$ & $2.41^{\mathrm{c}}$ & $2.24^{\mathrm{b}}$ & $79.54^{\mathrm{c}}$ & $3.27^{\mathrm{b}}$ & $3.29^{\mathrm{a}}$ & $0.67^{\mathrm{a}}$ \\
\hline 'Shishe-Kap' & $4.23^{\mathrm{a}}$ & $43.6^{\mathrm{b}}$ & $16.38^{\mathrm{bc}}$ & $0.018^{\mathrm{bc}}$ & $80.44^{\mathrm{c}}$ & $2.09^{c}$ & $4.34^{\mathrm{b}}$ & $5.14^{\mathrm{a}}$ & $8131^{\mathrm{bc}}$ & $1.72^{\mathrm{c}}$ & $1.14^{\mathrm{c}}$ & $0.68^{\mathrm{a}}$ \\
\hline 'Rubab' & $3.78^{\mathrm{c}}$ & $43.5^{\mathrm{b}}$ & $20.00^{\mathrm{a}}$ & $0.028^{\mathrm{ab}}$ & $81.4^{\mathrm{c}}$ & $1.98^{\mathrm{c}}$ & $6.36^{\mathrm{a}}$ & $4.93^{\mathrm{a}}$ & $86.77^{\mathrm{a}}$ & $1.83^{\mathrm{c}}$ & $1.25^{\mathrm{c}}$ & $1.28^{\mathrm{a}}$ \\
\hline 'Shalghami' & $3.78^{\mathrm{c}}$ & $48.2^{\mathrm{a}}$ & $17.07^{\mathrm{b}}$ & $0.027^{\mathrm{ab}}$ & $89.98^{\mathrm{b}}$ & $4.73^{\mathrm{a}}$ & $3.99^{\mathrm{b}}$ & $4.30^{\mathrm{ab}}$ & $80.12^{\mathrm{ab}}$ & $4.80^{\mathrm{a}}$ & $2.30^{\mathrm{b}}$ & $0.86^{\mathrm{a}}$ \\
\hline
\end{tabular}

Note: The dissimilar letters in each column indicate significant differences between them. 
Reducing sugar content was the highest in 'Ghand' $(5.81 \mathrm{mg} / 100 \mathrm{~g})$ and the lowest in 'Shishe-Kap' $(1.72 \mathrm{mg} / 100 \mathrm{~g})$ and 'Rubab' $(1.83 \mathrm{mg} / 100 \mathrm{~g})$. 'Ghand' had the maximum of glucose $(3.48 \mathrm{mg} / 100 \mathrm{~g})$ and the lowest content of glucose were found in 'Shishe-Kap' $(1.14 \mathrm{mg} / 100 \mathrm{~g})$ and 'Rubab' (1.25 mg/100 g) (Table 4). Glucose is the predominant sugar in pomegranate and amount of glucose is more than of fructose in this fruit (Melgarejo, 2000). The results of our research were lower than value $(5.7-7.6 \%)$ reported by Gadze et al. (2012). These results showed that the levels of reducing sugar, glucose and other physicochemical properties were different among various cultivars of pomegranate that could be due to existence of high genetic heterogeneity within the cultivars (Tehranifar et al., 2010).

'Rubab' had the highest content of total phenolics $(6.36 \mathrm{mg} \mathrm{GAE} / 100 \mathrm{ml})$ and total flavonoids (4.93 mg GAE/100 ml). The lowest content of total phenolics was found in 'Ghand' (1.78 mg
GAE/100 ml) and 'Shahvar' (2.41 mg GAE/100 ml). 'Shahvar' had the minimum of total flavonoids (2.24 mg GAE/100 ml) (Table 4). Tehranifar et al. (2010) found a significant difference in total phenolics concentration among the twenty varieties of pomegranate (295.79 to $985.32 \mathrm{mg}$ GAE $100 \mathrm{~g}-1$ ). The highest and the lowest antioxidant activity were detected in 'Rubab' (86.77 \%) and 'Shahvar' (79.54 \%) (Table 4). The reported levels of antioxidant activity in other researches were $10.37-67.46 \%$ for seven cultivars of pomegranate juices in Turkey (Tezcan et al., 2009) and 18.6-42.8 \% for eight pomegranate juices from Iran (Mousavinejad et al., 2009).

The differences in the genetic variability led to the variation in the biosynthesis of phenolic compounds among cultivars. There is a close correlation between total phenolic content and antioxidant activity (Tehranifar et al., 2010).

\section{CONCLUSIONS}

This study showed significant differences in some physical and chemical properties of five pomegranate cultivars grown in Iran. Among the five cultivars studied, the highest values of morphophysiological characteristics were observed in the 'Shishe-Kap' and 'Rubab'. The highest content of total phenolics and total flavonoids and the highest antioxidant activity was found in 'Rubab' cultivar. 'Ghand' had the maximum of reducing sugar level and glucose. Thus could be concluded, 'Shishe-Kap', 'Rubab' and 'Ghand' are appropriate for fresh consumption and health benefits. Provided information on the physicochemical properties of pomegranate cultivars can be useful for developing fruit processing industry and selection of superior desirable pomegranate genotypes for commercial cultivation. This research provides important information about physicochemical properties in some pomegranate cultivars grown in Iran. Since Iran has a high genetic variation, however, more studies of physical and chemical properties of pomegranate are required.

\section{REFERENCES}

Akbarpour V., Hemmati K.h., Sharifani M. 2009. Physical and chemical properties of pomegranate (Punica granatum L.) fruit in maturation stage. American-Eurasian J. Agric. \& Environ. Sci, 6 (4): 411-416.

Al-Maiman S.A., Ahmad D. 2002. Changes in physical and chemical properties during pomegranate (Punica granatum L.) fruit maturation. Food Chem, 76: 437-441. Doi: 10.1016/S0308-8146(01)00301-6
Al-Said F.A., Opara L.U., Al-Yahyai R.A. 2009. Physico-chemical and textural quality attributes of pomegranate cultivars (Punica granatum L.) grown in the Sultanate of Oman. J. Food Eng, 90: 129134. Doi: 10.1016/j.jfoodeng.2008.06.012

Anonymous. 2005. Statistical book of agricultural of Iran. Iranian Statistical Centre, Tehran, Iran.

Ashwell G. 1957. Colorimetric analysis of saccharides. In: colomick SP, Kaplan No, ds. Methods in 
enzymology. New York: Academic. Press INC, 3: 73-105.

Baronee T., Caruso F., Marra P., ottile F. 2001. Preliminary observations on some sicilian pomegranate (Punica granatum L.) varieties. Journal American Pomological Society, 55(1):4-7.

Cam M., Hisil Y., Durma G. 2009. Classification of eight pomegranate juices based on antioxidant capacity measured by four methods. Food Chem, 112: 721-726. Doi: 10.1016/j.foodchem.2008.06.009

Ercisli S., Agar G., Orhan E., Yildirim N., Hizarci Y. 2007. Interspecific variability of RAPD and fatty acid composition of some pomegranate cultivars (Punica granatum L.) growing in Southern Anatolia Region in Turkey. Biochem. Syst. Ecol, 35: 764-769. Doi: 10.1016/j.bse.2007.05.014

Gadze J., Prlic M., Bulic M., Leko M., Barbaric M., Vegoand Raguz M. 2011. Physical and chemical characteristics and sensory evaluation of pomegranate fruit of (Punica granatum L.) cv. Glavas. Origin Scientific Paper, 17: 3 - 4.

Gil M., Tomas-Barberan F.A. 2000. Antioxidant activity of pomegranate juice and its relationship with phenolic composition and processing. Journal of Agriculture Food Chemistry, 48: 4581- 4589. Doi: $10.1021 /$ jf000404a

Kashyap G., Gautam M.D. 2012. Analysis of vitamin C in commercial and naturals substances by Iodometric titration found in nimar and malwaregeion. Journal of Scientific Research in Pharmacy, 1(2): 77-78.

Khoshnam F., Tabatabaeefar A., Ghasemi Varnamkhasti M., Borghei A.M. 2007. Mass modeling of pomegranate (Punica granatum L.) fruit with some physical characteristics. Sci Hortic, 114: 21-26. Doi: 10.1016/j.scienta.2007.05.008

Kulkarni A.P., Aradhya S.M. 2005. Chemical changes and antioxidant activity in pomegranate arils during fruit development. Food Chem, 93: 319-324. Doi: 10.1016/j.foodchem.2004.09.029

Maccready R.M., Goggolz J., Silviera V., Owenc H.S. 1950. Determination of search and amylase in vegetables. Analytical chemistry, 22:1156-1158. Doi: $10.1021 / \mathrm{ac} 60045 \mathrm{a} 016$

Martinez J.J., Melgarejo P., Hernandez F., Salazar D.M., Martinez R. 2006. Seed characterisation of five new pomegranate (Punica granatum L.) varieties. Scientia Horticulturae, 110: 241-246. Doi: $10.1016 /$ j.scienta.2006.07.018
Melgarejo P., Artes F. 2000. Organic acids and sugar composition of pomegranate juice. Eur. Food Res. Technol, 4: 30-31.

Melgarejo P., Martinez-Nicolas J.J., Martinez-Tome J. 2000. Evolution of pomegranate juice anthocyanins during the ripening of fruit ofthree clones: ME16, VA1 and BA1. Options Mediterraneennes :Serie A. Seminaires Mediterraneens, 42: 123-127.

Miller G.L. 1959. Use of dinitrosalisylic acid reagent for determination of reducing sugars. Analytical chimestry, 32: 426-428.

Mousavinejad G., Emam-Djomeh Z., Rezaei K., Haddad Khodaparast M.H. 2009. Identification and and quantification of phenolic compounds and their effects on antioxidant activity in pomegranate juices of eight Iranian cultivars. Food chem, 115: 1274-1278. Doi: 10.1016/j.foodchem.2009.01.044

Olaniyi A.F., Umezuruike L.O., Karen, I.T. 2010. Chemical and Phytochemical Properties and Antioxidant Activities of Three Pomegranate Cultivars Grown in South Africa, Food Bioprocess Technol, 5(7): 2934-2940.

Ozgen M., Durgac C., Serce S., Kaya C. 2008. Chemical and antioxidant properties of pomegranate cultivars grown in the Mediterranean region of Turkey. Food Chem, 111: 703-706. Doi: 10.1016/j.foodchem.2008.04.043

Ozkan M. 2002. Degradation of anthocyanins in sour cherry and pomegranate juices by hydrogen peroxide in the presence of added ascorbic acid. Food Chem, 78 (4): 499-504. Doi: 10.1016/S03088146(02)00165-6

Rania J., Ne'jib H., Messaoud M., Mohamed M., Mokhtar T. 2008. Characterization of Tunisian pomegranate (Punica granatum L.) cultivars using amplified fragment length polymorphism analysis. Scientia Horticulturae, 115(3): 231-237. Doi: 10.1016/j.scienta.2007.09.002

Sarkhosh A., Zamani Z., Fatahi M. 2006. A review on medicinal characteristics of pomegranate (Punica granatum L.). Journal Of Medicinal Plants, 6 (22):13-24.

Sharman N., Bist H.S. 2005. Evaluation of some pomegranate (Punica granatum L.) cultivars under mid hills of Himachal Pradesh. ActaHortic, 696: 103-105. Doi: 10.17660/ActaHortic.2005.696.17

Shulman Y., Fainbertein L., Lavee S. 1984. Pomegranate fruit development and maturation. J. Horti. Sci, 48: 293-296. Doi: 10.1080/00221589.1984.11515196

Singh R.P., Murthy C., Jayaprakasha G.K. 2002. Studies on the antioxidant activity of pomegranate

Acta agriculturae Slovenica, 107 - 2, september 2016 
(Punica granatum L.) peel and seed extract using in vitro models. Journal of Agric. Food Chem, 50: 8186. Doi: 10.1021/jf010865b

Singleton V.L., Rossi J.A. 1965. Clorimetry of total phenolics with phosphomolybdic-phosphotungstic acid reagents. Am. J. Enol. Viticult, 16: 144-158.

Sun T., Ho C.T. 2005. Antioxidant activity of buck wheat extracts. Food Chemistry, 90: 743- 749. Doi: 10.1016/j.foodchem.2004.04.035

Tehranifar A., Mahmoodi-Tabar S. 2009. Foliar application of potassium and boron during pomegranate (Punica granatum) fruit development can improve fruit quality. Hort. Environ. Biotechnol, 50:1-6.

Tehranifar A., Zarei M., Nemati Z., Esfandiyari B., Vazifeshenas M.R. 2010. Investigation of physicochemical properties and antioxidant activity of twenty Iranian pomegranate (Punica granatum L.) cultivars. Scientia Horticulturae, 126: 180-185. Doi: 10.1016/j.scienta.2010.07.001
Tezcan F., Gultekin-Ozguven M., Diken T., Ozcelik B., Erim F.B. 2009. Antioxidant activity and total phenolic, organic acid and sugar content in commercial pomegranate juices. Food Chem, 115: 873-877. Doi: 10.1016/j.foodchem.2008.12.103

Valero C., Ruiz-Altisent M. 2000. Design guidelines for a quality assessment system of fresh fruits in fruit centers and hypermarkets. International Commission of Agricultural Engineering, vol 2.

Varidi, M. J. 1992. Chemical compositions and clarification probability of pomegranate extract. Master's thesis. univ. Tarbiat Modarres, Tehran, Iran.

Yang J., Martinson T.E., Liu R.H. 2009. Phytochemical profiles and antioxidant activities of wine grapes. Food Chemistry, 116: 332-339. Doi: 10.1016/j.foodchem.2009.02.021

Zarei M., Azizi M., Bashir-Sadr Z. 2011. Evaluation of physicochemical characteristics of pomegranate (Punica granatum L.) fruit during ripening. Cambridge Journals, 66: 121-129. 